Copyright (C) 2016 by Academic Publishing House Researcher

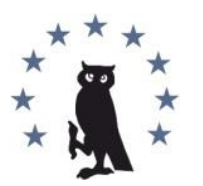

Published in the Russian Federation

European Researcher

Has been issued since 2010.

ISSN 2219-8229

E-ISSN 2224-0136

Vol. 102, Is. 1, pp. 25-43, 2016

DOI: 10.13187/er.2016.102.25

www.erjournal.ru

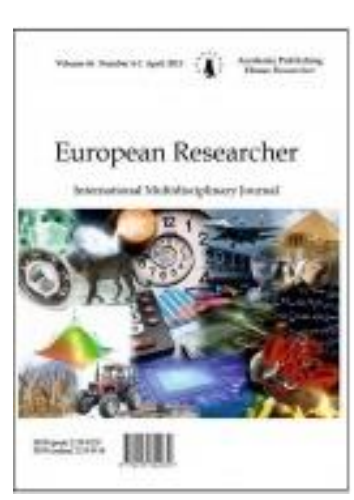

UDC 33

\title{
Life Satisfaction - Migrants from Serbia and Montenegro to Denmark: Case Study
}

\author{
${ }^{1}$ Goran Rajović \\ ${ }^{2}$ Jelisavka Bulatović
}

\author{
${ }^{1}$ Street Vojvode Stepe 252, Belgrade, Serbia \\ E-mail: dkgoran.rajovic@gmail.com \\ Doctor \\ ${ }^{2}$ College of Textile Design, Technology and Management \\ Street Starine Novaka 24, Belgrade, Serbia \\ E-mail: jelisavka.bulatovic@gmail.com
}

"It is strange how little it takes to be happy and even stranger how exactly that little we lack" Ivo Andrić (Vujović, 2007).

\begin{abstract}
The community of migrants from Serbia and Montenegro, although not numerous (about 8.00o), it is interesting to researchers because in Denmark the middle of which is economically dependent on, maintains its socio - economic identity, and therefore the quality of life. As an instrument for assessing quality of life of migrants from Serbia and Montenegro in Denmark, used a questionnaire was created by the World Health Organization and questionnaires evaluating quality of life created by Department of Psychology at the Royal College of Surgeons in Ireland, adapted to the needs of this research. Metric characteristics of the questionnaire were evaluated on a sample of 189 respondents - migrants from Serbia and Montenegro who live and work in Denmark. Despite the large variability answer most of these areas (respondents listed a total of 48 resort life as a determinant of their own quality of life), can be classified into the following eight global domains: health, emotional well-being, material well-being, interpersonal relationships, productivity or performance, safety, social communities and religions and spiritual domains of life. Displayed is the average value of the quality of life by gender. Personal values are ranging from $13-100 \%$ SM. In order to determine the differences in the index of quality of life in relation to age, conducted statistical testing the quality of life index difference between age groups. For respondents younger than 17-29 years, the average quality of life index was 68.68 with a standard deviation of 12.18. Quality of life index for the second age group (30-59 years) is 67.39 with a standard deviation of 12.17. For respondents 60 and over years, the average index is 66.48 , with a standard deviation of 7.07 .
\end{abstract}

Keywords: migrants, Serbia, Montenegro, Denmark, quality of life, areas quality of life.

\section{Introductory considerations}

Starting from the prehistoric and tribal communities, the question is what is at that time was the quality of life. Of course, the first place was that the individual is healthy; it is able to provide 
himself with enough food and females / males for their reproducing. When the year of fertile and having enough fruits and animals then man tribal community was overjoyed because all the rest of the time he was preparedness and formal communication with members of the tribe (Milivojević et al, 2011).

The man of modern times is much unhappy than man tribal community. The reason is that from my life expected a lot more, and requirements others toward him are far more pronounced (employer, family, school, society ...), and being unable to fulfill all that he is dissatisfied and less happy. Of course that the concept of quality of life was introduced much later, only in the last century, and if you are about happiness discussed by many philosophers since ancient times to today (Milivojević et al, 2011).

According Milivojevic et al (2011) in the literature on the quality of life we have dozens of definitions and models. In addition to general models of quality of life we find the models for specific groups of people (those who are sick, persons with developmental disorders, athletes ...). Thus, the models and the definition of quality of life differ depending on the author and the ruling schools. However, despite the fact that there are variations in individual visions continue to be implemented consistently establish uniform terminology for achieving uniformity of scientific research and application of models of quality of life in practice. Basically, it is based on a detailed assessment of the similarity (difference) in the framework of meetings preferences, opinions, behavior and values, which provides a clear meaning and understanding of all that is quality of life. Thus, so far developed models show the collective quality of life and personal values, priorities and expectations, while at the same time perform combining living conditions and traditional statistics.

So the first empirical study of "quality of life", i.e. the level of life and standard of living (level of living) to Gojčeta et al (2004), were created in the framework of Economic Sciences. Trgovčević et al (2011) suggest that the term "quality of life" first mentioned Pigou in 1920 in a book about economics and welfare, while the first documented use of the term in the medical literature; we meet 40 years ago in the field of transplantation medicine. The level of life determined on the basis of satisfaction of material needs, and the only indicator of social development was a national income. As most people as superior quality distinguishes health, there is a need for a definition of quality of life related to health (HRQoL - health related quality of life).

Over the years, the number of studies on quality of life is increasing, and the World Health Organization (WHO), provides definitions of quality of life. According to WHO (1998), quality of life is defined as the perception of individuals about their own position in life in the context of culture and value systems in which they live, as well as to their goals, expectations, standards and interests. It is a broad concept which covers: physical health of individuals, psychological status, material independence, social relations and their relations to the significant environmental characteristics.

Drewnowsky and Scott (1968) indicate that "the Geneva model of quality of life" that shaped the United Nations Institute for exploration of social development in Geneva in 1966, according to which the level of quality of life is defined as "the degree of satisfaction of material and cultural needs of society" and its indicators are: quality of food, housing, health, education, recreation, and safety of material gain. However, Allardt (1976) indicates the "Scandinavian model" according to which the quality of life depends on satisfying all universal human needs, it is of: 1) material needs (determined in the have): physical needs, the needs of existence, 2) social needs (determined with love): the need for security, belonging, acceptance, love and needs removal, 3) Personal needs (determined with be): the need for learning, self-actualization and personal development needs.

In determining the concept of quality of life in addition to economic and social indicators (which are objectively measurable), numerous researchers introduce and subjective indicators (measurable degree of satisfaction). Among the many authors on this occasion apostrophized: (Lewis, 1968; Smith, 1973, Knoh and Maclaran, 1978; Helburn, 1982; Pacione, 1984; Lay, 1991; Cella, 1992; Ira and Kollár, 1994; Diener and Suh, 1997; Sheldon and Elliot, 1999; Diener, Suh, Lucas, \& Smith, 1999; Diener, 2000; Dzurova and Dragomirecka, 2000; Hagerty et al, 2001; Boelhouwer, 2002; Diener et al., 2003; Beauchamp , 2004; Mandzuk and McMillan, 2005; Wu and Yao, 2006; Ryff and Singer, 2008; Jarholm, 2009; Aranđelović et al, 2010; Lucas and Diener, 2010; Slavuj, 2012; Rajović and Bulatović, 2015; Rajović and Bulatović, 2016).

Armstrong and Caldwell (2004) considering the importance of the term quality of life and its "rhetorical power", equating it with social, medical and technological progress. Keith (2001) and 
Schalock (2000) suggest that quality of life can be used as "sensitive concept that provides recommendations and guidelines". However, Schalock (2004) states that quality of life we can understand as "social circuit" and the "organizational concept" or "this entire together "it is as" systematic framework through which one can see efforts aimed at improving the lives of individuals". According to Kahn (2004) objectively measuring living conditions taking into account the modest share of the personal, subjective quality of life and / or well-being. Cummins (2000) focuses on the personal level of life satisfaction of individuals, regardless of the objective scarcity of its environment. It is worth to be invited to Hawking (1998), which emphasizes that the essence is not the existence or absence of a single theory, but only a better understanding of our existence.

In order to understand the changes of the concept of quality of life, it is necessary to know the essence of life and its interaction with the social order, and with the physical environment. At first, the quality of life boiled down to social standards ... and later begins with research needs and satisfaction of man and clear distinction is made between the objective and subjective quality of life, in the end of the last century, according to the theory of sustainable development, in a big way and entered the third dimension of the quality of life, which refers to the quality of the environment. In the last few years as the fourth dimension of quality of life are introduced science and technology development (Jakopin, 2011).

Table 1: A taxonomy of Quality of Life definitions

\begin{tabular}{|c|c|l|}
\hline Type & \multicolumn{2}{|c|}{ Name for type } \\
\hline I & (A) Expert/professional's definitions \\
\hline Global definitions & $\begin{array}{l}\text { The most common, general, type of definition - } \\
\text { usually say little about the possible components of } \\
\text { QOL. Usually incorporate ideas of } \\
\text { satisfaction/dissatisfaction } \\
\text { happiness/unhappiness. }\end{array}$ \\
\hline II & Component definitions & $\begin{array}{l}\text { Break down QOL into a series of components, } \\
\text { dimensions or domains, or idem tidy characteristics } \\
\text { deemed essential to any evaluation of QOL. }\end{array}$ \\
\hline II a & (Non-research-specific) & $\begin{array}{l}\text { Identify a number of dimensions of general QOL, but } \\
\text { may not necessarily claim to cover every possible } \\
\text { dimension. }\end{array}$ \\
\hline III & Focused definitions & $\begin{array}{l}\text { Explicitly tailor red to meet the objectives of a specific } \\
\text { piece of research. May therefore overlook or exclude } \\
\text { certain dimensions of QOL considered less relevant to } \\
\text { the research aims. }\end{array}$ \\
\hline III a & $\begin{array}{l}\text { Refer only to one or a small number of the dimensions } \\
\text { of QOL. }\end{array}$ \\
\hline III b & (Explicit) & $\begin{array}{l}\text { Focus on a small number of dimensions of QOL } \\
\text { considered essential to QOL, but does so explicitly. }\end{array}$ \\
\hline IV & (Implicit) & $\begin{array}{l}\text { Focus on one or two dimensions of the broader } \\
\text { concept of QOL, but implicitly, without making this } \\
\text { clear. }\end{array}$ \\
\hline
\end{tabular}

Source: Bell (2005) according to Farquhar (1995).

Global definitions are identified by Farquhar as the most common type within the expert literature. These are very general definitions that omit the possible components of QOL. Component definitions break down QOL into its constituent parts, dimensions or "domains", or identify key characteristics considered essential to evaluate QOL. These fall into two categories. The non-research specific will typically identify a number of dimensions of general QOL - both objective and subjective - although it may not claim to cover all the possible dimensions of QOL. A research-specific component definition, in contrast, is one where the writer has considered the 
concept of QOL specifically with regard to his or her own research focus. As a result, some possible dimensions of QOL may be overlooked or excluded from the definition because they are considered less relevant to the research focus (Bell, 2005).

Referring to research Farquhar (1995) prominent researcher Bell (2005) indicating on the third types are focused definitions. Either explicitly or implicitly these refer to just one component, or a minority of components, of QOL. Farquhar found these to be most common in the literature relating to health and functional ability. Explicit focused definitions, for example, were found most commonly in the health-related QOL literature where researchers focus on a small number of factors considered essential to QOL, but do so openly. In contrast implicit focused definitions concentrate on one or two components of the whole concept but without making this plain. Most commonly authors will use the term QOL without defining it, but will then operationalise it in terms of one or two measures, from which the reader may interpret a definition. But as Farquhar comments, "In these circumstances it is difficult for the reader to assess how the authors fully interpret the term the fourth type are combination definitions, those that are global definitions (type I) but which also specify components (type II).

Large research heterogeneity of approach to measuring quality of life stems from the different approaches to the concept of quality of life. In fact, today there are many approaches to measuring quality of life, which may vary between countries and between regional economic integration and organizations (egg use a different set of indicators to assess the quality of life are: the European Union, OECD, UNDP ...) (Ilić et al, 2010; Jakopin, 2011; Werner, 2012). However nevertheless in the present studies mostly used for testing the quality of life developed by the World Health Organization through the implementation of "WHOQOL-100" (WHOQOL Group, 1998) and adapted by different languages and cultures around the world.

The nineties years the last century WHOQOL group under the auspices of the World Health Organization began a project development of a common instrument for assessing quality of life, to be used around the world. WHOQOL-100 questionnaire consisted of several stages. The first phase involved the adoption of compliance with the definition of quality of life, as well as the establishment of an international approach to assessing the quality of life. In the second phase of development, research of the concept of quality of life in 15 different cultural centers, in order to determine the list of areas / aspects are important for quality of life assessment. In the third are phase of development, from a total of 236 questions (items), selected the 100 questions. It included the four questions from each of the 24 areas of quality of life and 4 questions related to the areas of overall quality of life and overall health. In this way WHOQOL-10O provides a detailed assessment of each specific area related to quality of life. However, in certain cases, the WHOQOL-10O proved to be too large for practical use, and is initiated Population Research WHOQOL-BREF questionnaire, which composition of 26 questions (WHOQOL Group, 1998).

According to WHOQOL Group (1998) survey consists of two parts: 1) The general part includes personal information about interviewee with a total of 6 issues (gender, age, education, marital status, as well as two issues related to the health condition); 2) The second part of the questionnaire includes 26 questions, of which the first two questions relating to the perception of the individual's quality of life and satisfaction with their own health, and the remaining 24 questions belonging to one of four domains: a) physical health (perform everyday activities, dependence on medical care; energy and fatigue, mobility, sleep and rest, the pain and inconvenience; working capacity); b) psychological health (physical and appearance; negative and positive feelings, self-esteem, concentration); c) social relationships (personal relationships, social support, sexual activity); g) environmental (financial income, freedom, physical security and safety; availability and quality of health care; housing conditions; leisure activities; opportunities for acquiring new information, transportation).

The questionnaire for the evaluation of quality of life, direct method of determining the importance of the area of quality of life "(Schedule for the evaluation of quality of life-SEIQoL: A direct weighting procedures for quality of life domains) was created at the Department of Psychology at the Royal College of Surgeons in Ireland. SEIQoL is implemented through a standardized and semi-structured interview which specifies the names and descriptions of the five areas that the person believes the main determinants of their own quality of life, then assessment of the state or functioning of individuals in each of these areas by self-assessment on a scale from 1 to 7 (where $1=$ the worst possible to $7=$ the best possible), and the importance of an individual 
gives to each of these areas (ranked by importance). It is not necessary that each area has a different rank, is allowed and the answer to all of these areas as important (O'Boyle et al, 1993).

\section{Research Methodology}

The community of migrants from Serbia and Montenegro, although not numerous (about 8.00o), it is interesting to researchers because in Denmark the middle of which is economically dependent on, maintains its socio - economic identity, and therefore the quality of life. How is it term quality of life is complex, it needs to be considered within the more theoretical approach or framework. So there are two interpretations: one provided by the respondents, and the other researchers (Rajović, 2014).

In order to obtain representative data in the survey, it is planned that a combination of surveys and interviews involving at $2 \%$ of respondents of the total number of Serbian and Montenegrin immigrants in Denmark, and about 200 participants. In the first stage, were selected settlements that represent migrants as a whole: Copenhagen, Hilerod, Frederiksberg, Helsingør, Næstved, Silkeborg, and Rødovre. The number of respondents in this case, determined on the basis of the inventory immigrants Rajovic (1993), corrected with the number of migrants from recent data Rajović (2014) and Rajović (2015). In the second stage, the author chose GR respondents the combination of accidental and deliberate choice, in order to ensure the quota. The planned number of respondents in the realization of surveys and interviews has been exceeded, but the stricter control logic at the end of the questionnaire dealt with a total of 189 questionnaires, representing a very high turnover of $96.2 \%$ of the planned sample. The second group of data related to the areas that make the personal determinants of quality of life of migrants and their universality and specificity, i.e. it was important to assess the importance of the area found in the personal quality of life and in the end determine how respondents evaluate their life (or level of functioning) on each of the above areas individually. As an instrument for assessing quality of life of migrants from Serbia and Montenegro to Denmark, use contemporary combination questionnaire was created by the World Health Organization and questionnaires evaluating quality of life was created by the Psychology Department at the Royal College of Surgeons in Ireland*.

"Specialized literature contains a great number of studies dealing with questions of the theory and methodology of the QoL. In spite of this, plurality or only partial, consensus prevails in opinion on the given theme. Even if it may seem that this situation is the result of the multidisciplinary nature of QoL, the differing views on the concept appearing in studies pertaining to the same scientific disciplines consistently point to the highly subjective nature of the concept. It is manifested in subjective perception and interpretation of QoL by any individual regardless of his/her qualifications or specialization. From the point of view of the scientific approach to QoL, above all definition or interpretation of the content of the concept, the related terminology, methodological basis and criteria dependence or criteria by which the QoL is estimated are the factors where a considerable plurality of views exists" (Ira et al, 2009). It is only possible to talk about partial consensus when the idea of a "two-dimensional" or "multidimensional" structure of QoL is accepted. In spite of terminological similarity (which is confusing to some extent) the two characteristics of QoL possess their individual content and meaning. Although an attempt was made to discern the content of two-dimensionality and multidimensionality, it is true that the term dimension still appears in the context of QoL in dual meaning. In connection with the question of defining the QoL but also of the relevant terminology the use of so-called meta-concepts should also be mentioned. Among the most frequently applied meta-concepts are: well-being, life satisfaction, happiness, health, quality of place, sustainability, and livability. Based on an extensive overview of the meta-concepts, arrived at the conclusion that due to their contents they all can be broadly comprised in the common quality of life concept (Ira et al, 2009).

Research procedure is based on research: Hughes and Hwang (1996), Anderson and Gerbing (1998), Nahid and Shamsuddin (2001), Vuletić and Mujkić (2002), Skevington et al (2004), Skevington et al (2004), Kler (2006), Liebig (2007), Bayram et al (2011), Ostling (2013), Kleven et al (2014). Research mentioned authors helped us to easily implement, it is defined the goals and results of the research.

\footnotetext{
* Expert support to the authors of the text in the analysis of the survey gave is Doctor Slobodan Ranđelović, professor of medical group of subjects on "Medical school" - Belgrade. Authors the thanks Doctor Slobodan Ranđelović.
} 


\section{Analysis and Discussion}

Demographic variables such as gender, age, education, socio-economic status I can be condition differences in objective living conditions and the manner in which an individual experiences and assess the quality of your life. The impact of demographic variables on subjective indicators of quality of life was examined in numerous studies, which showed different patterns of association in different cultures: Andrews and Withey, 1976; Watson et al, 1988; Van Oudenhoven and Willemsen, 1989; Wqaston and Klark, 1992; Ruff et al 1999; Wahl et al 2004; Lima and Novo, 2006; Lučev and Tadinac, 2008. Society may differ according to the expectations and standards relating to the standard of living and level of satisfaction and happiness, as well as to the objective conditions of life that are associated with certain demographic characteristics (Lučev and Tadinac, 2008).

Table 1 shows the distribution of respondents by age, gender, education and place of birth. Approximately 30.2\% of the respondents were born in Denmark, while $69.8 \%$ were born in Serbia and Montenegro. Of the total number of respondents (189) in research is participated 103 men or $54.4 \%$, or 86 women or $45.5 \%$. Of the total number of respondents born in Denmark (57), participated are 28 men and 29 women, respectively 75 men and 57 women born in Serbia and Montenegro. Most of the respondents born in Denmark (57.2\%) were in the age group of 17-29, while in the age group of 30-59 years participated $42.8 \%$ of respondents. Of the total number of births in Serbia and Montenegro (132), the majority of respondents were in the age group of 60 and over (50.0\%), while the total number of respondents in the age group of $30-59$ years was $34.1 \%$ in the group of $17-29$ years was $10.9 \%$.

Table 2: Respondents by place of birth, age, gender and educational, Source: Survey

\begin{tabular}{|c|c|c|c|c|c|c|}
\hline \multirow{2}{*}{ Study participants } & \multicolumn{3}{|c|}{ BIRTH PLACE } & \multicolumn{2}{c|}{ TOTAL } \\
\cline { 2 - 5 } & $\begin{array}{c}\text { Serbia and } \\
\text { Montenegro }\end{array}$ & \multicolumn{2}{c|}{ Denmark } & \multicolumn{2}{c|}{} \\
\hline & $\mathrm{N}$ & $\%$ & $\mathrm{~N}$ & $\%$ & $\mathrm{~N}$ & $\%$ \\
\hline \multicolumn{7}{|c|}{ GENDER } \\
\hline Female & 57 & 43.0 & 29 & 51.0 & 86 & 45.5 \\
\hline Male & 75 & 57.0 & 28 & 49.0 & 103 & 54.5 \\
\hline TOTAL & 132 & 100 & 57 & 100 & 189 & 100 \\
\hline \multicolumn{7}{|c|}{ AGE GROUPS } \\
\hline 17-29 & 21 & 10.9 & 33 & 57.2 & 33 & 17.5 \\
\hline $30-59$ & 45 & 34.1 & 24 & 42.8 & 69 & 36.5 \\
\hline 60 and more & 66 & 50.0 & - & - & 87 & 46.0 \\
\hline Total & 132 & 31.0 & 57 & 100 & 189 & 100 \\
\hline \multicolumn{7}{|c|}{ EDUCATION } \\
\hline Primary or less & 35 & 26.5 & 3 & 5.1 & 38 & 20.1 \\
\hline Secondary & 89 & 67.4 & 33 & 49.0 & 122 & 64.6 \\
\hline High School & 8 & 6.1 & 21 & 37.6 & 29 & 15.3 \\
\hline Total & 132 & 100 & 57 & 100 & 189 & 100 \\
\hline
\end{tabular}

According to most of the findings from the literature educational level was positively associated with pleasure and happiness (Ruff et al., 1999; Kling and Wing, 1999; Nezlek, 2000; Markus et al., 2004; Ryan and Huta, 2009), which is logical given that a higher level of education an individual provides a greater range of opportunities and resources available. In terms of education of the total number of births in Serbia and Montenegro participated in the study with primary school $26.5 \%$ of respondents with secondary education $67.4 \%$ and with higher school $6.1 \%$ of them. The educational structure of the total number of respondents born in Denmark in the research were involved with secondary education $49.0 \%$, with a higher school (students included) $37.6 \%$ and primary 3 respondents. 
Table 3: Names, frequency and percentage of nominated areas by age groups and in total

\begin{tabular}{|c|cc|cc|cc|c|cc|}
\hline Name of the area & \multicolumn{2}{|c|}{ Total } & \multicolumn{2}{c|}{$17-29$} & \multicolumn{2}{c|}{$30-59$} & \multicolumn{2}{c|}{60 and more } \\
\hline Health & 113 & 15,2 & 46 & 14,8 & 42 & 14,8 & 25 & 16,6 \\
\hline Family & 102 & 13,8 & 48 & 15,5 & 39 & 13,8 & 20 & 13,2 \\
\hline $\begin{array}{c}\text { Finance, Material } \\
\text { status }\end{array}$ & 84 & 11,3 & 39 & 12,7 & 33 & 11,5 & 13 & 8,6 \\
\hline Job & 83 & 11,2 & 41 & 13,3 & 29 & 10,2 & 13 & 8,6 \\
\hline Love & 72 & 9,7 & 29 & 9,4 & 34 & 11,9 & 9 & 6,0 \\
\hline Friendship & 64 & 8,6 & 36 & 11,7 & 17 & 5,9 & 11 & 7,3 \\
\hline Social life / Society & 26 & 3,5 & 11 & 3,6 & 11 & 3,8 & 4 & 2,5 \\
\hline Religion & 24 & 3,3 & 3 & 0,9 & 11 & 3,8 & 10 & 6,6 \\
\hline Sport & 19 & 2,7 & 9 & 2,9 & 9 & 3,1 & 1 & 0,7 \\
\hline Free time & 17 & 2,3 & 2 & 0,6 & 9 & 3,1 & 6 & 4,0 \\
\hline Career & 15 & 2,0 & 3 & 0,9 & 11 & 3,8 & 1 & 0,7 \\
\hline Spiritual Life & 15 & 2,0 & 2 & 0,6 & 3 & 1,1 & 10 & 6,6 \\
\hline Peace & 14 & 1,9 & 1 & 0,3 & 2 & 0,7 & 11 & 7,3 \\
\hline Entertainment & 14 & 1,9 & 8 & 2,6 & 6 & 2,1 & 0 & 0 \\
\hline Happiness & 13 & 1,8 & 7 & 2,3 & 5 & 1,7 & 1 & 0,7 \\
\hline $\begin{array}{c}\text { Interpersonal } \\
\text { relationships }\end{array}$ & 12 & 1,6 & 3 & 0,9 & 2 & 0,7 & 7 & 4,6 \\
\hline Housing issue & 12 & 1,6 & 5 & 1,6 & 2 & 0,7 & 5 & 3,3 \\
\hline hobby & 11 & 1,5 & 7 & 2,3 & 4 & 1,4 & 0 & 0 \\
\hline $\begin{array}{c}\text { Self-satisfaction, } \\
\text { "I" at peace with } \\
\text { herself }\end{array}$ & 11 & 1,5 & 2 & 0,6 & 6 & 2,1 & 2,1 & 2,0 \\
\hline Family life & 10 & 1,3 & 2 & 0,6 & 7 & 2,4 & 1 & 0,7 \\
\hline Music & 10 & 1,3 & 6 & 1,9 & 4 & 1,4 & 0 & 0 \\
\hline
\end{tabular}

Source: Survey

Involved are a total sample 189 respondents. Each participant was identified five areas that it considers the main determinants of satisfaction quality of life. There are total of 48 areas. In Table 2 are given the names and the frequency of allegations in areas that are designated for more than ten times the total sample. Respondents point out six areas with a high incidence of allegations in determining satisfaction with the quality of life. In the first place according to the frequency of health $(\mathrm{N}=113)$, then comes the family $(\mathrm{N}=102)$, finance and material status $(\mathrm{N}=$ $84)$, job $(\mathrm{N}=83)$, love $(\mathrm{N}=72)$ and friendship $(\mathrm{N}=64)$. On further analysis it was found that all respondents in defining determinants of satisfaction with quality of life cite at least one or more of these six areas. In addition, 10 areas have fewer incidences of allegations out of 10. Such a great number of different areas are a reflection of individual differences among respondents, reflecting the individual specificity of satisfaction with the quality of life.

For the purpose of further analysis of the results with respect to age, the subjects were divided into three age groups. The first age group of 17-29 years $(\mathrm{N}=33)$, the other from 3059 years $(N=69)$ and the third of 60 years and older $(N=87)$. As in the overall data, in the group of younger respondents highlights six areas that are most prevalent as determinants of satisfaction with quality of life. The most frequently stated family $(\mathrm{N}=48)$, followed by health $(\mathrm{N}=46)$, job $(\mathrm{N}=41)$, and finance and monetary situation $(\mathrm{N}=39)$. A total of 41 different designated area. Among subjects other age groups, 30-59 years old, found a different distribution of answers and rank the importance of certain areas. This group of respondents, who mostly belong to the active working population, the most common appoints the following four areas as the determinants of satisfaction with the quality of life: health $(\mathrm{N}=42)$, families $(\mathrm{N}=39)$, love $(\mathrm{N}=34)$, and finance and monetary situation $(\mathrm{N}=33)$. According importance, in the first place comes health, then family and third in love and fourth finances and monetary situation. Total appears in 25 areas, which is less compared to those younger age groups. In the group of respondent's third age group, 
60 years or more, three areas stand out for the frequency of allegations. These are: health $(\mathrm{N}=25)$, families $(\mathrm{N}=20)$, and business and finance and monetary situation $(\mathrm{N}=13)$. Number of domains that occur as determinants of satisfaction with the quality of life is the smallest in this group of respondents was 14. And these respondents was within the group attached most importance to health, then family and area related to business and finance and monetary situation.

Table 4: Three most important life areas by age group, Source: Survey

\begin{tabular}{|c|c|c|c|}
\hline Rank & \multicolumn{3}{|c|}{ Age groups } \\
\hline & $17-29$ & $30-59$ & 60 and more \\
\hline 1 & Family & Health & Health \\
\hline 2 & Health & Family & Family \\
\hline 3 & Job & Love & $\begin{array}{c}\text { Job/ Finance and material } \\
\text { status }\end{array}$ \\
\hline
\end{tabular}

The core of the concept of "quality of life" of each individual is his experience satisfaction with life and its course and the conditions, prospects, possibilities and limitations that each individual has in their life (Krizmanić i Kolesarić, 1989). This assessment, based on the individual experience and the aspirations, wishes and values of the individual, determined physiological assembly characteristics of the individual and objective conditions in which he lives. Cognitive and connective characteristics of each individual determine the range and quality of interaction with the environment, its adaptability to changes in the physical and social environment, as well as the changes that occur within an organism (Petz et al 2005.). Thus, the health of the group of respondents third age group 60 and over by the frequency of allegations in the first place $(\mathrm{N}=25)$. Also, it should be noted that not only their own health but also the health of their loved ones, the respondents consider the allegations to be important in their own quality of life. With the right Vuletic (2013) emphasizes that Ill health is certainly one of the external factors that negatively affect the lives of individuals. The impact of a damaged health quality of life is multidimensional. Not only does affects in terms of physical symptoms, thus limiting operation, but they the present and indirect effects such as the changes in working abilities, potential isolation, increasing dependency on others, bad habits ... Self-assessment of health status and quality of life are an integral part of population studies. These measures show the importance of the subjective perception of health and quality of life independent of objective measures. Considering that chronic diseases and conditions have become part of everyday life for a large part of the population, the question of quality of life in the circumstances.

Marital status and family proved to be a significant factor in the subjective aspect of quality of life in a number of different studies: people who are married or in a consensual union are happier and more satisfied than nonmembers (Wahl et al., 1998, Diener et al., 1999, Burckhardt et al., 2003, Wahl et al., 2004). There are some findings which indicate that that this relationship is particularly pronounced in developed societies (Veenhoven, 1983, Blom and Listhaug, 1988, Lima and Novo, 2006, Wani et al., 2013) what kind is and Denmark. Life of respondents in Denmark is largely takes place within family, which in addition to its members connects relatives and compatriots. Its integrated functions are especially reflected in the socializing with strangers. According to composition or size, family immigrants mainly "covers marital union - husband and wife, the nuclear family - a married couple and their children, extended family - parents, children, grandchildren, relatives of the first degree, and relatives community - the second instance relatives. The largest number of respondents in Denmark lives in a nuclear family. Grandparents, as well as in homeland actively participate in the upbringing and preservation of their grandchildren. It is noticeable that for over 40 years living and working in Denmark among migrants from Serbia and Montenegro, the family changed significantly and as an institution, and on how to educate. While we were immediately after immigrating to Denmark could be characterized as strict hierarchy, in the previous period from arrival till today, she is increasingly based on cooperativeness of all family members, although it noted that in terms of ethnicity retain the respect of generational affiliation. Thus the members of the second and third generation migrants, noted due respect to the elderly 
and as far as the position of women, to her yet always receives a considerable burden of family responsibilities (Rajović, 2011). So the family in a group respondents the first age group, according to the frequency of allegations in the first place $(\mathrm{N}=48)$. Respondents emphasize that they are accepted and Danish principle of substantive independence of their children. Upon entering the marriage, their kids are instantly apartment of Danish society, which most often of equipment parents of personal financial resources. So, the family is in these cases maintain characteristics, which has brought from their homeland. The biggest difference to family life in homeland is early economic independence. Almost all the migrants how emphasize the participants know each other and they know who is whence and when he came in Denmark. They have recorded and phone numbers each - other and serve up the phone book, which is given to every owner free fixed phone number in Denmark. Family life and kinship relations among our migrants are highly developed. The migrants maintain close links with their relatives, not only in Denmark but also from those who live in Sweden and Germany. Not forgets not even relatives who remained in homeland, and mutual visits are frequent, especially during the holiday season, which many of our migrants carried out in homeland.

Job occupies a large space in the life of nuclear family migrants. Parents spend a great deal of time on work and education of children. Denmark is huge attention to children. Habitually is that children are they find independent beings which adults should to hear and as early as possible, children should be yes engage in autonomous decision. How in families of our emigrants, as well as the Danish children's institutions and schools place that children getting used to the responsibility of and learn responsibility in so much as it is possible in relation to their age. Danish laws require that children have the right to care and safety according to children is to be treated with due the respect for their personality. Therefore it is prohibited and punishable by law apply force. Parental responsibility is to provide children the love and care and creating a safe environment for their growth.

In the group of respondents third age group, area jobs and finance, or material status most frequent of allegations sharing third place $(\mathrm{N}=13)$. An important are feature of the migrants' families, who lives in Denmark, are certainly financial, and material status. From what can be noticed and see the standard of living of migrants in Denmark is really on a high level. Almost all the migrants have very nice comfortable apartments, equipped with modern furniture and appliances. Individually, each family has a car. From individual interviews with respondents, we found out that most of them own houses built in homeland or purchased apartments, and owners of business premises mainly in the country. Also, a number of migrants has own savings "an old foreign currency savings", which them were not allowed to raise 27.04.1991 and today as pointed out by respondents devalued. Foreign currency savings depositor's estimate that the newest Law from 2004 on the restitution of assets by 2017 does not mean anything to them, because they emphasize the how many of them will not be a living

The group respondents other age groups, areas of love stand out for the frequency of allegations third $(\mathrm{N}=34)$. Rightly Halauk (2013) emphasizes that love is the most desirable emotions, deeply rooted in us, which of course emphasize the respondents. Basically, love different in color (figure emotions) and in sinewy (the victim whom we are willing to tolerate). All primarily referring to conjugal love, which is the beginning and romantic and passionate. Partnership relations are marked by sexual attraction and the existence of passion thereby yes partners everyone wants exclusively for itself. There is no doubt that such a person in those moments live a high quality of life! Explaining love, we must mention a few others that we could clarify the picture called emotion - love. Respondents emphasize the and which coincides with research Halauk (2013) that the greatest love of parents to children, the love of grandchildren, love of brother and sister, the love of parents, love of my grandfather and grandmother, love for friends and love for the pet. As for the volume, it is indisputable that she strongest against children, specifically according to grandchildren. Today it was confirmed that each age has its own love that in youth and in old age varies in color and intensity. 
Table 5: Quality of life index by gender and for the whole sample, Source: Survey

\begin{tabular}{|c|c|c|c|}
\hline Respondents & $\mathrm{N}$ & Arithmetic mean & Standard deviation \\
\hline Men & 103 & 61.65 & 13.77 \\
\hline Women & 86 & 61.01 & 14.29 \\
\hline Total & 189 & 61.36 & 14.03 \\
\hline
\end{tabular}

Table 5 is presented average value of the quality of life by gender. Personal are values ranging from 13-100 \% SM. And if the female respondents, on average, have a lower value than the total extent of personal quality of life, the difference was not statistically significant $(t=0.3775, \mathrm{df}=187$; $\mathrm{p}>0.05$ ). In order to determine the differences in the index of quality of life in relation to age, conducted statistical testing the quality of life index difference between age groups. As can be seen in Table 6 respondent's first age group (17-29) achieved the highest values while respondent's third age group (6o and over) achieved the lowest values. However, this difference has not been statistically significant $\mathrm{F}=0.7896 ; \mathrm{p}>0,05$.

Table 6. Quality of life index by age groups, Source: Survey

\begin{tabular}{|c|c|c|c|c|}
\hline Age groups & Arithmetic mean & $\begin{array}{c}\text { Standard } \\
\text { deviation }\end{array}$ & Minimum & Maximum \\
\hline $17-29$ & 68.68 & 12.18 & 16.66 & 100.00 \\
\hline $30-59$ & 67.39 & 12.17 & 33.33 & 100.00 \\
\hline 60 and more & 66.48 & 7.07 & 50.00 & 83.33 \\
\hline
\end{tabular}

For respondents younger than 17-29 years, the average quality of life index was 68.68 with a standard deviation of 12.18. The theoretical range in which they can move the index value is $o$ to 100. The range in which is range of indexes for this age group is from 16 to 100 degrees. Quality of life index for the second age group (30-59 years) is 67.39 with a standard deviation of 12.17. Individual values are within the range of 33 to 100 degrees. This is the age group with the highest variability of individual values and the largest range of indices. For respondents 60 and older, the average index is 66.48, with a standard deviation of 7.07, and in the range of values from 50 to 83 .

Finally, we show the indicators of quality of life in function of mature age man that is what it that is dominated by ages and stages of life cycle is are presented in Table 7. There are age-related, dominant in the life of the key groups of indicators._The difference is evident in each of these phases.

Table 7: Indicators of quality of life in function of mature life span man

\begin{tabular}{|c|c|c|c|}
\hline Lifetime time & Time period & Dominant in life & $\begin{array}{l}\text { Key groups of } \\
\text { indicators }\end{array}$ \\
\hline & & End of school & Are represented by \\
\hline Maturity & $\begin{array}{c}\text { women } 19 \text { to } 30 \\
\text { men } 21 \text { to } 35\end{array}$ & $\begin{array}{l}\text { Selection of titles } \\
\text { Economic }\end{array}$ & $\begin{array}{c}\text { sets } \\
\text { All four indicators }\end{array}$ \\
\hline Wound & women 31 to 45 & $\begin{array}{l}\text { independence } \\
\text { Love and selection of }\end{array}$ & $\begin{array}{c}\text { dimensions of quality } \\
\text { of life: }\end{array}$ \\
\hline & men 36 to 50 & $\begin{array}{c}\text { partners } \\
\text { Starting }\end{array}$ & $\begin{array}{c}\text { Economic } \\
\text { Social }\end{array}$ \\
\hline Median & & Children & Environment \\
\hline & $\begin{array}{c}\text { women } 45 \text { to } 70 \\
\text { men } 50 \text { to } 70\end{array}$ & $\begin{array}{c}\text { Social status } \\
\text { Contribution to the }\end{array}$ & $\begin{array}{l}\text { Science and } \\
\text { Technology }\end{array}$ \\
\hline Late & & $\begin{array}{c}\text { Community } \\
\text { Health } \\
\text { Sex }\end{array}$ & Systems of values \\
\hline
\end{tabular}




\begin{tabular}{|c|c|c|c|}
\hline Lifetime time & Time period & Dominant in life & $\begin{array}{l}\text { Key groups of } \\
\text { indicators }\end{array}$ \\
\hline $\begin{array}{c}\text { Age } \\
\text { Of the } 70 \text { years } \\
\text { since the death }\end{array}$ & $\begin{array}{c}\text { Of the } 70 \text { years since } \\
\text { the death }\end{array}$ & $\begin{array}{c}\text { Maintenance and } \\
\text { service } \\
\text { Health } \\
\text { Decent life in old age } \\
\text { Attention and care by } \\
\text { Family and society } \\
\text { Friendship } \\
\text { Jan range of interests } \\
\text { Creating a strategy for } \\
\text { Long life }\end{array}$ & $\begin{array}{c}\text { Health } \\
\text { Health services } \\
\text { Economic status } \\
\text { Systems of values } \\
\text { Attention and Care } \\
\text { Social needs } \\
\text { Interests } \\
\text { Striving for long life } \\
\text { Preparing for death }\end{array}$ \\
\hline Death & & & $\begin{array}{c}\text { Health } \\
\text { Fear of death } \\
\text { Lightweight death }\end{array}$ \\
\hline
\end{tabular}

Source: Milivojević et al (2015).

Thus, the method for determining indicators and indices of quality of life in this period, as well as life satisfaction and happiness are not much different and in full compliance with the applicable methodologies. According to Milivojević et al (2015) goals, needs, desires, expectations and attitudes change with the phases of the life cycle from generation to generation of human population. The problem arises for complex system levels where for practical reasons it is not possible for a longer period on the same sample continuously measure the value of life quality of life satisfaction, subjective well-being and happiness. Only on the same sample and the same individuals as possible to make conclusions about trends and laws by which these variables change. For now, the only such study was conducted by Harvard University, USA. The project started in 1938 and lasted for a full 75 years and it was attended by 268 male respondents. Measurements included the astonishing range of psychological, anthropological and physical characteristics-from personality type to the IQ of the habit of drinking to family relations ... Analysis of collected data and the results of research led to many discoveries that require revision attitudes in the field of quality of life and happiness.

\section{Conclusion}

Our research evidence based on similar studies Bell (2005), Schalock (2004), Pavićević (2004), Herček (1985), Rokach, (1989), Smith et al(1998), Selvamanickam et al (2001), Sheanhar et al (2001), Castels (2006), Narchal (2007), Daniel (2007), Cattaneo et al (2013), Dustmann and Frattini (2014), Otrachshenko and Popova (2014), indicates the following important findings in research:

1. QOL and well-being are also a concern of the social indicators movement, which developed in both Scandinavia and the US in the 1960 s and 1970 s out of a feeling that economic indicators alone could not reflect the QOL of populations. Over the past 30 years this has become a fast growing discipline now fully embraced by governments and public sector agencies worldwide, seeking to measure and compare changes in QOL within and between communities, cities, regions and nation states. Major studies of QOL, for example, have been sponsored by organisations such as UNESCO, the OECD, and the World Health Organization (WHO),

2. QOL emerged as an academic discipline in its own right in the 1970s, with the establishment in 1974 of the peer reviewed scientific journal Social Indicators Research, founded and edited by Alex Michalos. Since then the volume of academic articles concerned with QOL and well-being issues has steadily increased. Schalock reports that since 1985 alone over 20,900 academic articles have appeared in the international literature containing the term "quality of life" in their title. A second key academic publication is The Journal of Happiness Studies, a multidisciplinary journal which provides a forum for discussion of what it describes as the two main traditions in happiness research (1) speculative reflection on the good life and (2) empirical investigation of subjective well being. The International Society for Quality-of-Life Studies 
(ISQOLS) serves as a forum for academic researchers working in this field, encouraging interdisciplinary research and methodological debate and development. Our literature search produced a final selection of 244 articles, the majority academic but with a significant minority drawn from commissioned consultancy work and reports by public sector agencies,

3. More intensive departure of citizens from the former Yugoslavia for temporary work abroad, recorded in the mid-sixties years the last century. To work outside the country, went mostly younger population from rural areas. Yugoslavia was the only European communist country, who sent the labor force in the capitalist countries. The first stage of labor migration is mass labor immigration to the country's capitalist economy. The second, "family reunification", when workers burst, to reduce isolation, save money and make life easier in a foreign environment, bring their spouses and children or establish a new family. In a situation where migrant begin to start families when their children start attending Western European schools, then migrants decide in most cases to permanently stay. The third phase is the "permanent residence "and development of new ethnic minorities,

4. In migrants, on life satisfaction affecting assessment in the difference between: the new living conditions, living conditions of their close in the mainstream, and that which they had in the past. "Factor change of residence" can cause feelings of loneliness, because it involves the relocation and reduced the number of social relationships, separation from family that provides a sense of belonging. Factors which during relocation influence the social and emotional loneliness of migrants are reasons for departure from the country of origin, the problems of coping with the new environment, cultural differences, foreign language, unemployment, education problems, the consequences of social isolation, responsibility and the necessity of making important decisions for which they were not prepared,

5. However, Baumeister and Dewall (2005) show that for the migrant's change of residence may be affected positively or negatively, but that primarily depends on the attitudes and relationships of migrants to moving as well as individual personality traits. Loneliness occurs when not satisfied the need for attachment to other people (Weiss,1973) and the dissatisfaction of these needs leads to lower satisfaction with life (theory of self-determination). Haslberger and Brewster (2007) emphasizes that something better social skills can help women (who are socially sensitive ...) to learn faster, being safer, and that easier to find their way in the new environment and culture, as opposed to male migrants which according to the Gergen and Gergen (1986) and Haneš (2012) the adults (first generation immigrants) in the spirit of tradition and preserving the national identity. However, we note that for other especially third-generation migrants from Serbia and Montenegro in Denmark and this barrier lose its significance. Generally speaking, in the beginning, life satisfaction migrants in the host community may be reduced due to language barriers, cultural differences, decreased social interaction (Hossen and Westhues, 2012; Mirzaie et al,2014). However, the process of independence in the new environment is faster, because the individuals working active, and in addition to the length parallel stay and with years of age, to a greater extent the satisfy needs for autonomy and competence, which have a positive impact on life satisfaction, and independence,

6. Frank et al (2014) relying on research Otrachshenko and Popova (2011), Polgreen and Simpson (2011) and Massey and Akresh (2006) confirming yes differences between the average life satisfaction of immigrant groups and their source-country populations may also be attributable to unobserved factors. For example, life satisfaction itself may play a role in individuals' decision to migrate. Although some research indicates that individuals with lower levels of happiness are more likely to migrate, others argue that those who lack the financial resources to migrate likely have the lowest levels of satisfaction within source countries. In addition, life satisfaction is a significant predictor of whether an immigrant remains in the host country. Immigrants who are unhappy in the host country are more likely to return to their source country or to move to another country. The result is an over-representation of immigrants in the host country with high life satisfaction. Data limitations prevent an examination of this issue in this paper,

7. Data on the number of Yugoslav immigrants in Denmark are shown in the "statistics on foreigners", volume 2 in the editorial office Bruun and Hamer (1991). The said statistics records, the total number of migrants from the former Yugoslavia in Denmark in 1967 amounted to - 358, 1974-6.802, 1991-10.039. However, the Danish statistics does not show migrants from the former Yugoslavia in Denmark, in the republics of the former Yugoslavia. About the exact number of 
migrants from Serbia and Montenegro in Denmark it is difficult to give precise data. According to unofficial estimates, in Denmark have about 8.00o citizens of Serbia and Montenegro. According to Vladimir Radulovic ambassador of the state union Serbia and Montenegro in Copenhagen (2005): "It's hard to say how many of our people have the citizenship of Serbia and Montenegro, because in the meantime, 40-50 percent of them accepted the Danish citizenship, which is why they have to give up previous citizenship, because Denmark does not allow dual citizenship",

8. The research life satisfaction: migrants from Serbia and Montenegro in Denmark included a total of 189 respondents. Despite the large variability answer most of these areas (respondents listed a total of 48 resort life as a determinant of their own quality of life), can be classified into the following eight global domains: health, emotional well-being, material wellbeing, interpersonal relationships, productivity or performance, safety, social communities and religions and spiritual domains of life. Respondents really stand out six areas with a high incidence of allegations in determining satisfaction with the quality of life. In the first place according to the frequency of health $(\mathrm{N}=113)$, then comes the family $(\mathrm{N}=102)$, finance and material status $(\mathrm{N}=$ 84), job $(\mathrm{N}=83)$, love $(\mathrm{N}=72)$ and friendship $(\mathrm{N}=64)$,

9. The average index of quality of life according to sex the in the range of $13-100 \%$ SM. In order to determine the differences in the index of quality of life in relation to age, respondents first age group (17-29) achieved the highest values while respondent's third age group (6o and over) achieved the lowest values. For respondents younger than 17-29 years, the average quality of life index was 68.68 with a standard deviation of 12.18. Quality of life index for the second age group (30-59 years) is 67.39 with a standard deviation of 12.17 . For respondents 60 and older, the average index is 66.48, with a standard deviation of 7.07, and in the range of values from 50 to 83 ,

10. Gives life in Denmark, the best are shows a study Organization for Economic Cooperation and Development (OECD). The OECD in its initiative 'Better Life' has investigated how various aspects of life affect the common good of a society, and the quality of life in different countries. In addition to the salary, the OECD for each country taking into accounts the balance between work and private life. The index for a better life is calculated using three factors: 1) The amount of time spent on personal activities, 2) the percentage of employed women with children between 6 and 14 years, 3) the number of employees in the workplace are spends more than 50 hours a week. The first on this scale is Denmark. The Index balance between work and free time totaled 9.1. Time devoted to leisure activities ranged around 16.31 hours, the percentage of employed women with children 6-14 years was 78\%, employees in the workplace spend more than 50 hours per week is $0.02 \%$ (www.nadlanu.com ).

The system of values is the basis of man's personality, his life attitudes and form of life. Value systems are not the same for all individuals, and they are generally significantly differing from individual to individual. However, each person has to adapt its system of values of national and civilization value system. But the basic system the value of individual is the basis for its life satisfaction, quality of life and happiness. She constantly compares the fulfillment of your life with your value system and assesses the qualitative attributes this fulfillment. We know that the legality of same origin, but the conditions of origin are not. On the other hand, the basic value system of the individual suffers significant changes during its life cycle (childhood, adolescent, mature people, old people). Quality of life, life satisfaction and happiness are a direct function of age; however, respondents' statements refer only to the moment of interview and may not be accurate for the whole life of man. In other words, the value system suffers significant and often radical changes, depending on the age and condition of life (Milivojević et al, 2015).

Finally, Denmark is a model example of state where the persistent and deliberate work, culture and democracy realizes legally, economically and socially stable society, attractive for other countries and peoples. In this and such a society, your place is migrants from Serbia and Montenegro. Hence the author himself GR has a lot of sympathy for this country and its people, which is understandable, because he lives in Denmark narrower part of the family and wider family (Rajović, 2011).

\section{References:} Belgrade.

1. Vujović, M., (2007), Thoughts for eternity, Independent publishing agency "Zlaja", 
2. Milivojević, J., Arsić, A. K., Milovanović, K. K., Đokić, S., Savović, I.,(2011), The new philosophy of quality of life, 38 National Conference on quality, 6 conference on quality of life, FO Quality Festival, B-121-130, Kragujevac.

3. Gojčeta, M., Joković-Oreb, I., Pinjatela, R., (2008), Some aspects of the quality of life of adolescents with and without cerebral paralyze, Hrvatska revija za rehabilitacijska istraživanja, 44(1): 39-47.

4. Trgovčević, S., Kljajić, D., Nedović, G., (2011), Social Integration as Determinant of the quality of life of persons with traumatic paraplegia, Godišnjak 6(4): 493-506.

5. WHO (1998), The world health report: life in 21 century-a vision for all, Geneva

6. Drewnowsky, J., Scott, W., (1968), The level of Living Index - New Version, UNRISED, Genève.'

7. Allardt, E., (1976), Dimension of Welfareina Comparative Scandinavian Study, Acta Sociologica, 19(3):, 227-239.

8. Lewis, G. M., (1968), Levels of Living in the North-Eastern United States c. 1960: A New Approach to Regional Geography, Transactions of the Institute of British Geographers, 45, 11-37.

9. Smith, D., (1973), An introduction to welfare geography, Department of Geography and Environmental Studies, Johannesburg, University of the Witwatersrand.

10. Knox, P. L., MacLaran, A., (1978), Values and perceptions in descriptive approaches to urban social geography, in: D. Herbert and R. Johnston, (Ed.), Geography and the Urban Environment, John Wiley, Chichester, Sussex, 197-247.

11. Helburn, N., (1982), Presidential address: Geography and the Quality of Life, Annals of the Association of the American Geographers, 72(4), 445-456.

12. Pacione, M., (1984), Evaluating the quality of the residential environment in a high-rise public housing development, Applied Geography, 4(1), 59-70.

13. Lay, V., (1991), Quality of Life social strata in Croatia - Social structuring welfare, social structure and the quality of life in Croatia, Zbornik radova, IDIS, Zagreb, 1-12.

14. Cella, F. D., (1992), Quality of life: the concept, Journal of Palliative Care, 8(3),8-13.

15. Ira, V., Kollár, D., (1994), Behavioural-geographical aspects of environmental quality, GeoJournal,32(3), 221-224.

16. Diener, E., Suh, E., (1997), Measuring quality of life: Economic, social, and subjective indicators, Social Indicators Research, 40, 189-216.

17. Sheldon, K. M., Elliot, A. J., (1999), Goal striving, need satisfaction, and longitudinal well-being: The self-concordance model, Journal of Personality and Social Psychology, 76, 482497.

18. Diener, E., Suh, E. M., Lucas, R. E., Smith, H., (1999), Subjective well being: Three decades of progress, Psychological Bulletin, 125, 276-302

19. Diener, E., (2000), Subjective well-being: The science of happiness and a proposal for an national index, American Psychologist, 55, 34-43.

20. Hagerty, M.R., Cummins R.A., Ferriss A.L, Land, K., Michalos, A., Peterson, M., Sharpe, A., Sirgy, M.J., Vogel, J., (2001), Quality of Life Indexes for National Policy: Review and Agenda for Research, Soc Indic Res.,55(1),1-96.

21. Boelhouwer, J., (2002), Quality of Life and Living Conditions in the Netherlands, Social Indicators Research, 58(1), 113-138.

22. Diener, L., Oishi, S., Lucas, R. E., (2003), Personality, culture, and subjective well-being: Emotional and cognitive evaluations of life, Annual Review of Psychology, 54, 403-425

23. Beauchamp, T.L., (2004), Does Ethical Theory Have a Future in Bioethics?, $J$ Law Med Ethics, 32(2),209-17

24. Mandzuk, L.L., McMillan, D.E., (2005), A concept analysis of quality of life, J Orthop Res., 9(1), 12-8.

25. Wu, C. H., Yao, G., (2006), Analysis of factorial invariance across gender in the Taiwan version of the Satisfaction With Life Scale, Personality and Individual Differences, 40, 1259-1268.

26. Ryff, C. D., Singer, B. H., (2008), Know thyself and become what you are: A eudemonic approach to psychological well-being, Journal of Happiness Studies, 9,13-39

27. Jarholm, B., Albin, M., Johansson, G., Wadensjo, E., (2009), Perspective of working life research, Scand $J$ Work Environ Health, 35(5),394-6. 
28. Aranđelović, M., Nikolić, M., Stamenković, S., (2010), Relationship between Burnout, Quality of Life and Work Ability Index - Directions in Prevention, Scientific World Journal, 10, 766-77.

29. Lucas, R. E., Diener, E., (2010), Subjective well-being. In M. Lewis, J.M. Haviland-Jones, L., Feldman Barrett (Eds.). Handbook of emotions (pp. 471-484), New York, London: The Guilford Press.

30. Slavuj, L., (2012), The objective and subjective indicators in the study of the concept of quality of life, Geoadria, 17(1), 73-92.

31. Rajović, G., Bulatović, J., (2015), Different attitudes toward the quality of life concept, Azerbaijanian Journal of Economics and Social Studies, 4, 70 - 93.

32. Rajović, G., Bulatović, J., (2016),Life as a geographical theme - one more contribution to the study of quality of life, World Scientific News, 28, $41-57$.

33. Armstrong, D., Caldwell, D., (2004), Origins of the Concept of Quality of Life in Health

Care: a Rhetorical Solution to a Political Problem, Social Theory and Health, 2(4),361-71.

34. Keith, K.D., (2001), International Quality of Life: Current Conceptual, Measurement, and Implementation Issues, In: Glidden LM, editor. International Review of Research in Mental Retardation, 24, San Diego: Academic Press.

35. Schalock, R.L., (2000), Three Decades of Quality of Life, Focus Autism Other Dev Disabl, 15(2): 116-27.

36. Schalock, R.L., (2004), The Concept of Quality of Life: What We Know and Do Not Know, J Intellect Disabil Res., 48(3):203-16.

37. Kahn, N.B., (2004), The Future of Family Medicine: A Collaborative Project of the Family Medicine Community, Ann Fam Med, 2 (Suppl 1): s3-32.

38. Cummins, R.A., (2000), Objective and Subjective Quality of Life: an Interactive Model, Soc Indic Res, 52 (1): 55-72.

39. Jakopin, E., (2011), Measurement of prosperity and quality of life, Business and Finance, Available from: http://www.bif.rs (11.03.2014).

40. Bell, D., (2005), Quality of Life and Well-being: Measuring the Benefits of Culture and Sport: Literature Review and Thinkpiece, Scottish Executive Social Research.

41. Farquhar, M., (1995), Definitions of quality of life: a taxonomy, Journal of advanced nursing, 22(3), 502-508.

42. Ilić, I., Milić, I., \& Aranđelović, M. (2010). Assessing quality of life: Current approaches, Acta Medica Medianae, 49(4).

43. Werner, S. (2012). Subjective well-being, hope, and needs of individuals with serious mental illness, Psychiatry research, 196(2), 214-219.

44. The WHOQOL Group (1998), Development of the World Health Organization WHOQOL BREF Quality of Life Assessment, Psychological Medicine, 28: 551-558.

45. O'Boyle, C.A., McGee, H., Hickey, A., Joyce, C.R.B., Browne, J., O'Malley, J., (1993), The Schedule for the Evaluation of Individual Quality of Life. Administration Manual. Department of Psychology, Royal College of Surgeons in Ireland.

46. Rajović, G., (2011), Demographic characteristics of the modern labor migration from Montenegro to Denmark, GeoScape, 6( 1-2): 2-10.

47. Rajović, G., (2013), Some socio-geographic characteristics of modern labor migration from Serbia and Montenegro to Denmark: social life and social relations migrants, International Letters of Social and Humanistic Sciences, 2: 1-17.

48. Rajović, G., (2014),Geographical contribution of contemporary labour migration from Serbia and Montenegro to Denmark, International Journal of Migration and Residential Mobility, 1(1): $28-49$.

49. Rajović, V., (1993), Montenegrins in Denmark, Nikšić:"Unireh".

50. Rajović, G., (2014), Some characteristic of ethnic identity -Case study: migrants from Serbia and Montenegro to Denmark, Antrocom: Online Journal of Anthropology,10( 2), 187-224.

51. Rajović, G., (2015), Organization and Activities of Migrants from Serbia and Montenegro in Denmark: a Case Study, European Geographical Studies, 6(2): 92-110.

52. Ira V., Andraško I., Michalek A., Podolak P., (2009), Quality of life: geographical research in Slovakia, Geographia Slovaca,26,101-120. 
53. Hughes, C., Hwang, B., (1996). Attempts to conceptualize and measure quality of life, Quality of life, 1, 51-61.

54. Anderson James, C., Gerbing David, W., (1998), Structural equation modeling in practice: a review and recommended two-step approach, Psychological Bulletin, 103(3):411-423.

55. Nahid, A., Shamsuddin, A.F., (2001), Immigration and the unemployment benefit programme in Australia, Applied Economics, 33(12): 1587-1597.

56. Vuletić, G., Mujkić, A., (2002), What makes the personal quality of life: A study on a sample of Croatian urban population, Liječnički vjesnik, 124(2), 64-70.

57. Skevington, S.M., O'Connel, Kathryn A., The WHOQOL Group (2004), Can we identify the poorest quality of life? Assessing the importance of quality of life e using the WHOQOL-100", Quality of Life Research, 13(1): 23-34.

58. Skevington, S.M., Lotfy, M., O’Connell, K. A., (2004), The World Health Organization's WHOQOL-BREF quality of life assessment: Psychometric properties and results of the international field trial, A report from the WHOQOL Group, Quality of Life Research, 13(2): 299310 .

59. Kler, P., (2006), Overeducation among tertiary educated immigrants to Australia: A longitudinal study, Labour Economics Research Group, University of Queensland, Discussion Paper, (9), 39.

6o. Liebig, T., (2007), The Labour Market Integration of Immigrants in Denmark, OECD Social, Employment and Migration Working Papers, Head of Publications Service OECD, France.

61. Bayram, N., Thorburn, D., Bilgel, N., (2011), The quality of life of Turkish migrants in Sweden: a survey to determine the psychometric characteristics of the instrument 100 the quality of life of the World Health Organization, Migracijske i etničke teme, 27(1): 39-55.

62. Ostling, A.,(2013), An overview of highly skilled labour migration in Denmark with a focus on Indian nationals, CARIM-India Research Report 2013/43, Robert Schuman Centre for Advanced Studies, San Domenico di Fiesole (FI): European University Institute.

63. Kleven, H. J., Landais, C., Saez, E., Schultz, E., (2014), Migration and Wage Effects of Taxing Top Earners: Evidence from the Foreigners' Tax Scheme in Denmark, The Quarterly Journal of Economics, 129(1): 333-378.

64. Andrews Frank M. \& Withey Stephen B. 1976. Social Indicators of Well-Being: Americans Perception of Life Quality. New York: Plenum.

65. Watson D. Clark L. A. \& Tellegen A. 1988. Development and validation of brief measures of positive and negative affect: the PANAS scales. Journal of personality and social psychology, 54(6), 1063.

66. Van Oudenhoven J. \& Willemsen P. 1989. Ethnic Minorities: Social Psychological Perspectives (Tinke M.(ed.). Amsterdam: Swets \& Zeitlinger.

67. Ryff Carol D., Magee William J. Kling Kristen C. \& Wing Edward H. 1999. Forging macro-micro linkages in the study of psychological well-being, in: C. D. Ryff and V. Marshall (ed.). The Self and Society in an Aging Process. New York: Springer, pp. 247-278

68. Wahl Astrid K. RustØen T., Hanestad Berit R., Lerdal A. \& MoumT. 2004. Quality of life in the general Norwegian population, measured by the Quality of Life Scale (QOLS-N). Quality of life research, 13(5),1001-1009.

69. Lima Maria L. \& Novo R. 2006. So far so good? Subjective and social well-being in Portugal and Europe. Portuguese Journal of Social Science, 5(1), 5-33.

70. Lučev I. \& Tadinac M. 2008. The Quality of Life in Croatia-the Connection between Subjective and Objective Indicators as well as Temperament and Demographic Variables with a Reference to Minority Status. Migracijske i etničke teme, 24(1-2), 67-89.

71. Kling K. C. \& Wing E. H. 1999. Forging Macro-Micro Linkages in the Study of Psychological Well-Being. The Self and Society in Aging Processes, 247.

72. Nezlek J. B. 2000. The motivational and cognitive dynamics of day-to-day social life. The social mind: Cognitive and motivational aspects of interpersonal behavior, 92-111.

73. Markus H. R., Ryff C. D., Curhan K. B., \& Palmersheim K. A. 2004. In their own words: Well-being at midlife among high school-educated and college-educated adults. How healthy are we, 273-319. 
74. Ryan R. M. \& Huta V. 2009. Wellness as healthy functioning or wellness as happiness: The importance of eudemonic thinking (response to the Kashdan et al. and Waterman discussion). The Journal of Positive Psychology, 4(3), 202-204.

75. Krizmanić, M., Kolesarić, V., (1989), The attempt conceptualization of the term "quality of life" Primijenjena psihologija, 10(1989), $179-184$.

76. Petz, B., et al (2005), Psychological dictionary, Jastrebarsko: Naklada Slap.

77. Vuletić, G., (2013), Self-perceived health and quality of life in Bjelovar - Bilogora counties: regional differences and specificities, Radovi Zavoda za znanstvenoistraživački $i$ umjetnički rad u Bjelovaru, (7), 213-222. Belgrade.

78. Rajović, G., (2011), Montenegrin immigrants in Denmark, "The Agency PC system",

79. Wahl, A., Burckhardt, C., Wiklund, I., \& Hanestad, B. R. (1998). The Norwegian Version of the Quality of Life Scale (QOLS-N). Scandinavian journal of caring sciences, 12(4), 215-222.

80. Burckhardt, C. S., Anderson, K. L., Archenholtz, B., \& Hägg, O. (2003). The Flanagan quality of life scale: Evidence of construct validity. Health and Quality of Life Outcomes, 1(1), 59.

81. Veenhoven R. 1983. The Growing Impact of Marriage, Social indicators research,12 (1), $49-63$.

82. Blom, S., Listhaug, O., (1988), Family and quality of life, Tidsskrift for samfunnsforskning, 29(1), 5-28.

83. Wani, N. A., Dar, K. A., Wani, R. Y., (2013), Relationship between marital adjustment and socio-cultural determinants, Indian Journal of Health and Wellbeing, 4(1), 31.

84. Halauk, V., (2013), The quality of life in health and disease, Radovi Zavoda za znanstvenoistraživački i umjetnički rad u Bjelovaru, (7), 259-269.

85. Milivojević,J., Đorđević,J., Stojanović,S.,(2015), Quality of life, life satisfaction and happiness during the whole life cycle of men,10 National Conference on quality of life, Quality Festival, B 89 - B 98, Kragujevac.

86. Herček, E.,(1985), Postwar migration perspective of Europe, Migration issues, 1( 1): 520.

87. Rokach, A., (1989), Antecedents of Loneliness: A Factor Analysis, Journal of Psychology (123), 369-384.

88. Smith, W.K., Kevin, W., Avis Nancy, E., Aaman Susan, F., (1998), Distinguishing between equality of life and health status in quality of life research: a meta-analysis", Quality of Life Research, 8(5): 447-459.

89. Selvamanickam, S., Zgryza, M., Gorman, D., (2001), Coping in a New World: TheSocial and Emotional Wellbeing of Young People from Culturally and Linguistically Diverse Backgrounds. Brisbane: Queensland Transcultural Mental Health Centre, Queensland Health and Youth Affairs Network of Queensland Inc.

90. Shenkar, S., Carlson, D., Billington, R., Orley, J., The WHOQOL Group (2001), The WHO quality of life assessment instrument (WHOQOL-BREF): the importance of its items for cross-cultural research, Quality of Life Research, 10(8): 711-721.

91. Castels, S.,(2006), Guest workers in Europe: A Resurrection?, International Migration Review, 40(4): 741-746.

92. Narchal, R., (2007), Migration: Destruction and reconstruction of the self. Sensoria: A, Journal of Mind, Brain \& Culture, 3(1), 55-64.

93. Daniel,O.,(2007), Foreign workers: Rethinking Yugoslav Economic Migrations towards the European North-West through Tran nationalism and Popular Culture", In Imagining Frontiers, Contesting Identities, eds. Steven G. Ellis and Lud'a Klusáková, Pisa University Press, Pisa.

94. Cattaneo, C., Fiorio, C. V., Peri, G., (2013). Immigration and careers of European workers: effects and the role of policies, IZA Journal of European Labor Studies, 2(1), 1-26.

95. Dustmann, C., Frattini, T., (2014), The fiscal effects of immigration to the UK, The economic journal, 124(580), F593-F643.

96. Otrachshenko, V., Popova, O., (2014), Life (dis) satisfaction and the intention to migrate: Evidence from Central and Eastern Europe, The Journal of Socio-Economics, 48, 40-49.

97. Pavićević, A.,(2004), Some issues of external migrations of Yugoslavia after World War II, Journal of Ethnographic Institute of the Serbian Academy of Arts and Sciences, 57: 129-137. 
98. Baumeister, R. F., DeWall, C. N., (2005), The I nner dimension of social exclusion: Intelligent thought and self-regulation among rejected persons. In K. D. Williams, J. P. Forgas, \& W. von Hippel (Eds.), The social outcast: Ostracism, social exclusion, rejection, and bullying (pp. 53-73). New York, NY, US: Psychology Press.

99. Weiss, R. S., (1973), Loneliness: The experience of emotional and social isolation, Cambridge, MA: MIT Press.

100.Haslberger, A., Brewster, C., (2007), Domains of expatriate adjustment with special emphasis on work. In Cadiz University's 6th International Workshop on Human Resource Management, Jerez, Spain.

101. Gergen, J., Gergen, M. M., (1986), Social psychology, Berlin: Springer Verlag.

102. Haneš, O., (2012), Socio-demographic characteristics, social distance and stereotypes among students in Banja Luka, Primenjena psihologija, 5(1), 59-79.

103.Hossen, M. A., Westhues, A., (2012), The medicine that might kill the patient: structural adjustment and its impacts on health care in Bangladesh, Social work in public health, 27(3), 213228.

104.Mirzaie, G., Ahmady, K., Ali Mhrabe, H., Masoenlavasane, G., Azadfallah, P., (2014), The prediction of lifestyle according to personality traits, Journal of Behavioral Sciences, 8(2), 177-184. 105. Bruun, I., Hamer,O., (1991), "Statistikker over udlændinge, ingen sekunder, Danmarks statistik 1991.ar“.

106.Frank, K., Hou, F., Schellenberg, G., (2014), Life Satisfaction among Recent Immigrants in Canada: Comparisons with Source-country Populations and the Canadian-born, Analytical Studies Research Branch Research Paper Series, 363,5-23.

107. Otrachshenko, V., Popova, O., (2011), Life (dis)satisfaction and decision to migrate: Evidence from Central and Eastern Europe, Arbeitsbereich aus dem Osteuropa - Institut Regensburg, Arbeitsbereich Wirtschaft, Migration and Integration.

108.Polgreen, L.A., Simpson, N.B., (2011), Happiness and international migration, Journal of Happiness Studies, 12, 819-840.

109. Massey, D.S., Akresh, I.R. (2006), Immigrant intentions and mobility in a global economy: The attitudes and behavior of recently arrived U.S. immigrants, Social Science Quarterly, 87 (5), 954-971.

110. Statement V. Radulović (2005), Ambassador of the State Union Serbia and Montenegro in the Copenhagen newspaper "Blic", Available from: http://www.blic.evropa.net (26.08 2005).

111. Why is life in Denmark the highest quality, Available from: http://www.nadlanu.com (16.08.2015).

112. Milivojević, J., Đorđević, A., Stojanović, S., (2015), Functional link between quality of life and system of values, 42 National Conference on quality, 10 conference on quality of life, Quality Festival, L5-1-L5-12, Kragujevac.

УДК 33

\title{
Степень удовлетворенности жизнью - мигранты в Дании из Сербии и Черногории: пример
}

\author{
${ }^{1}$ Горан Райович \\ 2 Джелисавка Булатович
}

${ }^{1}$ Улица Vojvode Stepe 252, Белград, Сербия

E-mail: dkgoran.rajovic@gmail.com

Доктор

${ }^{2}$ Колледж текстильного дизайна, технологии и управления, Сербия

Улица Starine Novaka 24, Белград

E-mail: jelisavka.bulatovic@gmail.com

Аннотация. Сообщество мигрантов из Сербии и Черногории, хотя и не многочисленное (около 8,00о), представляет интерес для исследователей, так как в Дании 
часть из которых являются экономически зависимыми, они сохраняют свою социальноэкономическую личность, и, следовательно, качество жизни. В качестве инструмента для оценки качества жизни мигрантов из Сербии и Черногории в Дании используется вопросник, созданный Всемирной организацией здравоохранения и анкеты, оценивающие качество жизни, созданные кафедрой психологии в Королевском колледже хирургов в Ирландии, адаптированые к потребностям данного исследования. Метрические характеристики анкеты были оценены на образце 189 респондентов - мигрантов из Сербии и Черногории, которые живут и работают в Дании. Несмотря на большой разброс ответов большинстве из этих областей (респонденты перечислили в общей сложности 48 и показатели курортной жизни использовали в качестве определителя собственно качества жизни), могут быть классифицированы на следующие восемь глобальных доменов: здоровье, эмоциональное благополучие, материальное благополучие, межличностные отношения, производительность или эффективность, безопасность, социальные сообщества и религии и духовные домены жизни. Отображается среднее значение качества жизни по полу. Личные ценности, начиная от 13-100 \% СМ. Для того, чтобы определить различия в индексе качества жизни в зависимости от возраста, провели статистический анализ качества разности показателей жизни между возрастными группами. Для респондентов моложе 1729 лет, средний индекс качества жизни был 68.68 со стандартным отклонением $12,18$. Индекс качества жизни во второй возрастной группе (30-59 лет) является 67,39 со стандартным отклонением 12.17. Для респондентов 60 и более лет, в среднем индекс составляет 66,48 со стандартным отклонением 7,07.

Ключевые слова: мигранты, Сербия, Черногория, Дания, качество жизни, качество жизни области. 